骨髄並びに未梢血; 体外組織培養に

\author{
於ける単球系について \\ 第 3 編 \\ 家免骨髄体外組織培養飞於ける組織球，䋐維芽細胞と \\ 単球との比較並びそ相互化生有無の吟味 \\ 附. 全 編 の 総 括 \\ 岡山大学医学部平木内科教室 (主任 : 平木 潔教授) \\ 松木茂
}

[昭和 34 年 1 月 10 日受稿]

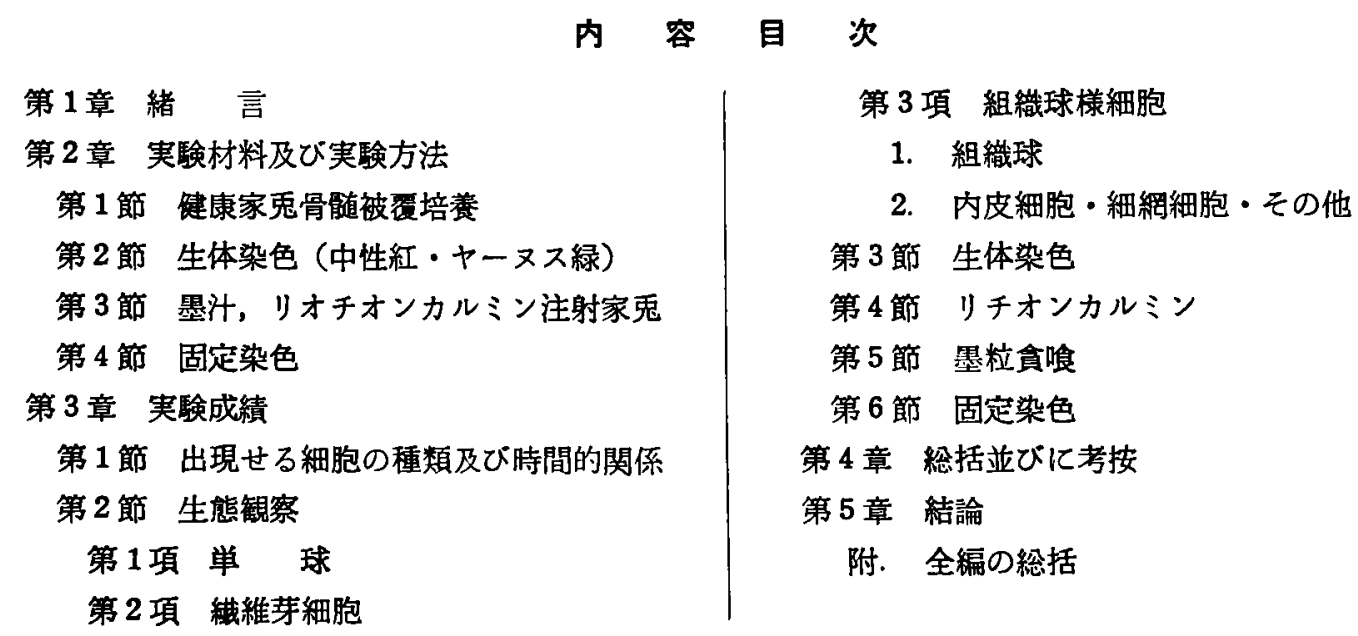

第1章 緒言

健康家克骨髄及び健康人骨髄の被夏培養法による 単球の所見は第 1 編に於て詳述したが，培養後 24 時 間を経過すると原組織周辺より紻維芽細胞が次で組 織球が出現してくる.

単球とてれらの細胞との関係については，現今ま で単球の発生学的研究や網状内皮系の矿究に於いて 種々の異論があり，各々の細胞間の化生について諭 ぜられている. 即ち Bloom10) は単球より組織球に 変化する事を，Maximow7)は単球より組織球に更 に織維芽細胞に変化する事を, Möllendorff7177273) 一派は綞維芽細胞より単球となり単球より組織球に なる事を認め, Seemann ${ }^{88)}$ は組織球には組織固有 のものと単球から変化したものがあると述へている.
又 Carrelu Ebeling13)14) は単球及び組織球より織 維芽細胞に, 緎維芽細胞より組織球に変ることを, Lewis \& Lewis64)66) は単球が組織球乃至貪喰細胞 に変じ更に巨大細胞にも変る事を観察している. 本 邦に於てむ関96)は細網細胞より算球・組穖球に又 䄉維芽細胞が炎症時に於いて突起を退縮さして単球 ・組織球汇変ると述へているが，天野3)5）は単球系 の独立を主張し，単球と組織球・纎維芽細胞とは相 互に移行しないとしている.

然しとにかく以上の如く組織球・䄳維芽細胞は 古来単球之非常に密接な関係があるとされ，少くと む单球類縁関係の細胞と目した学者が多い，低つて

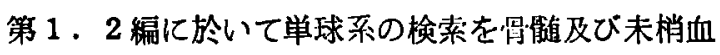
の休外組織培窇によつて行つて来たので，本編に於 いては家克骨髄被復培費によつて出現するてれらの 
細胞の生態観察，貪喰能及び生体染色，培養組織の 固定染色所見より，それぞれの細胞の形態学的・機 能的特徽を明らかにし, 相互に化生の有無を検索せ んとした.

\section{第 2 章 実験材料及ひ実倹方法}

第 1 節 健康家兔骨骮被覆培澺

第 1 編に於て詳述した如く, 培養組織として幼若 健康家兔大腿骨骨面を細片としたものを用い，培地 支持体は趾康家兔へパリン加血整を，発育促進物質 として家鵎胎児圧搾液を用いて被覆培養法を施行し， 培垱時間每に取出し $37.0^{\circ} \mathrm{C}$ 顕微鏡加温装置内で鏡 検し培福経過及び生態所見の観察を行つた。

第 2 節 生体染色

教室田村の方法に準じて施行した．即与培養時に 中性赤及びャーヌス緑を添加したのでは, 本編の細 胞観察の如く少くとも24時間以後の観察に於ては培 地自体が色素に染り細胞所見む十分に見られないの で，培養時間每に被璋硝子をはがし0.05\%中性赤及 び0.005\%ャーヌス緑を培養組織上汇適下し再びパ ラフィンにて十分に封じてから $37.0^{\circ} \mathrm{C}$ に保ち鏡検 した。

第3 節 墨汁及びリチオンカルミン注射家 鬼骨髄

㯬康家鬼耳静脈よりリチオンカルミン 2.5\%の の のを体重 $1 \mathrm{~kg}$ 当り $3.8 \mathrm{ec}$ の割で 7 日間每日注射 し, 最後の注射より 3 時間後に大腿骨䪔を取出し被 覆培養を行う。

健康家克耳静脈より，稀釈・滤過堿菌せる壆汁を 体重 $1 \mathrm{~kg}$ 当り $7 \mathrm{cc}$ の割で $3 \sim 7$ 日間毎日注射し， 最後の注射より 3 時間後に大腿骨䯣を取出し被覆培 養を行う。

培费後時間の経過と共に出現せる細胞について買 粒会喰及びリチオンカルミン染色を観察した。

第 4 節 固定並びに染色

培坊標本を時間每に取出して被覆硝子をはがし， Zenker-Alkohol-水醋液又は Bouin 氏液にて固定し， ギムザ染色を施行し 鏡検した（此の方法は第 1 編 にて詳述した.)

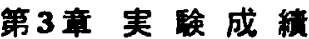

第 1 節 出現せる細胞の種類及び時間的関 係

培義後略々24時間を過ぎると原組織より増生帯に 向つて大なる紀銼形の細胞即ち緎維芽細胞の一部か
出現してくる．時間の経過と共にその数は增し原組 織全周より放射状に增生帯に向つて增殖してくる. 培荃後36時間目頃より原組織のすく周辺で䋐維芽細 胞の間に主として類円形なるも種くの型をした組織 球が出現する．然し尚極く少数にしか認められない，

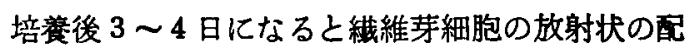
列増殖は盛となり，原組織周辺部の薄くなつた所で は緎維芽細胞が原組織像に沿つて平行に並九でいる のと又值角方向に並んでいるのが見られる．増生帯 に出た䄉維芽細胞は互に樹枝状に吻合しているのが 認められる。文組織球の出現む著明となりその数も 増加する. 培養後 6 日になると䄳維牙細胞の増殖も 略々停止し，9 日目以後には漸次崩壊像をとる.

尚，単球は第 1 編に記載の如く24時間以後は次第 飞衰元，48時間以後は淵次崩壊するが，9 日目に於 ても尚，少数の単球が組織球・維維芽細胞の間にみ られ，その中には運動型も認められる。

第 2 節 生態観察

第 1 項 単 球

第 1 編記载の如く細胞全周より旗状偽足を出して, D 型運動をなし，48時間以後は潄次崩壊像をとる。

第 2 項 䋐維芽細胞

細胞の大さは血液細胞に比し遥加に大きく個々の 大さは不定であるが，細胞の中央はふくらみ両尖端 は次第に細くなり定型的な紡錘型を呈する．尖端の 細くなつた部分は一方は原組織に向い，一方は増生 帯周辺部に向い，多くのものは尖端は 1 条であるが 分岐をむつて 2 条或は 3 条となつているのも認めら れ，他の䋐維芽細胞之樹枝状に交錯吻合しているの が認められる，細胞膜は透光性が強い為明瞭にみら れない場合が多く，顆柆によつて細胞型を形造つて いる感しである．核は胞体の中心部の細胞膨大部に 見られ棈円形を呈し，核膜は薄く非常に明るくみえ る. 胞体顆柆は光をよく反射する明るい感じて，大 小不同なく中等大，均質性で胞体内に一局に並んて 重り合う事なく，核周は疎であるが他の部には密に 並んでおり，細胞尖端の細い部分迄十分につまり一 列に並んている。顆柆の胞体内運動や流動は認めら れない（第1図）

細胞運動や変形は短時間内に於ては全く認められ ないが，2〜3 日の間隔で同じ細胞を鏡検すると多 少の変形，位置移動が認められる. 
第 1 図䄉維一芽細胞

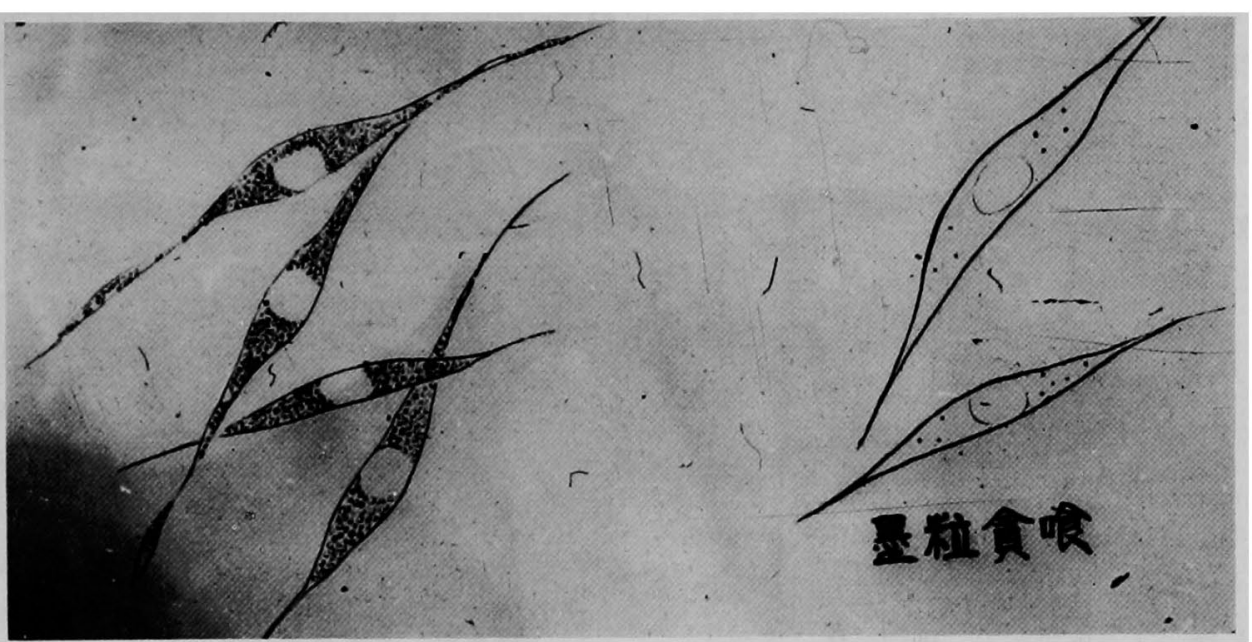

\section{第 3 項 組織球様細胞}

\section{1. 組織球}

一般に大型であるが，かなり大きいるのから小さ いものまであり且つ多形性を示すが類円形を呈する あのが多い，細胞膜は明らかでなく胞体内には微細 顆粒が充満している感じで，顆粒はや〉黒く見え胞 体内が污れているように感じられる，核は胞体の略 々中央に位置しているか或は僅かに偏在し，顆粒の ため核膜は明かでなく核のある所は顆粒が少いため にや」明るく見える. 顆粒は微細顆粒の他に大顆粒, 中等大顆粒の大小不同がみられ，互に重り合い入り
混り，胞体内には赤血球や崩壊せる白血球の貪喼が 認められる事もある.

運動及び変形は活溌ではないが認められ，特徵と するところは細胞全周より触手状，梀状の偽足を盛 に出沒さしていることである，偽足運動の盛な時は 細胞全周より密に触手状棘状突起を出沒させ，复え てくると数ケ所より出沒さしているのがみられる.

しかし単球様の旗状偽足は認められない。

尚組織球胞体が菱形・紡鍾形をとれる場合には偽 足形成が認めがたく，大小不同の光をよく反射する 中等大顆杧がある.（第 2 図）

織球

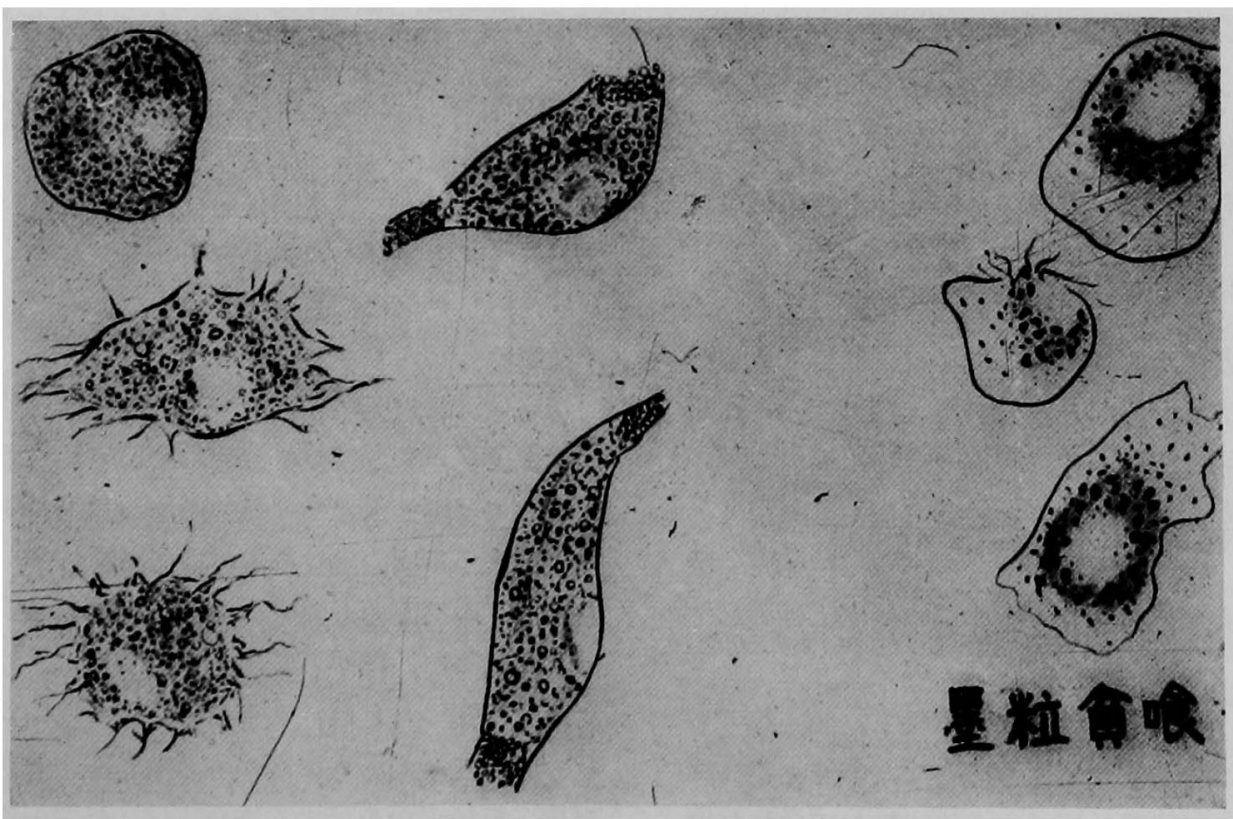

2. 内皮細胞, 細網細胞，その他 䄉維芽細胞，組織球の他に出現せる細胞は非常に
稀で，全く顆粒のない透明感が強い細胞で胞体に凹 凸のあるもの，織維芽細胞様の顆粒を有し好中球に 
類似した遊走をするすの，組織球と同様の外観を呈 しや小小型で偽足出没の全くないもの等が稀に見ら れ，細網細胞乃至内皮細胞の範詈に属するもの之思 われたが，数が少く細胞種を決定するに至らなかつ た.

第 2 節 生体染色

䋐維芽細胞は中性赤添加後 1 時間では，細胞全体 が非常に薄く均質に中性赤の色素に染り, 胞体内の 顆粒が稍谈赤色の色が強いのもみられるが，增生帯 内の単球，好中球，組織球に比し非常に炏く一見染 つていないように思える．3時間後では稍染色度を 增し，胞体中央の核を除いて微細同大の中性赤顆柆 を認める. $4 \sim 5$ 時間後では次第に強く染るが中性 赤顆粒は互に融合する事はなく，細胞全体任存在す るが中には校周に稍多いものや細胞端には見られぬ ものもある. 6 時間以後になると中性赤顆柆は稍粗 大になる. 7 時間以後になると次第に腿色が始り 8 時間以後になると增生帯周辺部の緎維芽細胞には全 く褪色したのも認められる。無添加の場合に比し䋐 維芽細胞の破罗が早期にあらわれる.

ヤーヌス緑添加は再三施行したがヤーヌス網染色 顆粒は認められなかつた.

組䅧球は一般に中性赤によく染り，弱㹡大に於て あ濃染の状態がよくうかがわれつ，中性赤添加 1 時 間後では種々の段階のむのが認められる. 即ち

（一）. 全く中性赤の色をとらす無添加之同様 のもの.

（土）ごくわすかに中性赤に染るが尚中性赤 顆粒の明膫でないもの.

(+); 胞体内は均斦性に中性赤に唯り，胞体内 の固有顆粒む十分に見られ少数の微細中性赤顆粒の あるもの.

（\#）・ 中等度に染色され固有顆粒は見られる が稍不明膫となり，細胞全体に顆粒と混して色素が いつけ゚いに広り，核のみ未染のまっ残つている感じ で，細胞全体に微細中性赤顆柆之え机に重つて浱い い大きな中性赤顆柆があるが融合のないもの.

（计）中性赤顆粒の瀜合があり，胞体内に数 ケの円形の大顆柆を作り，全体が中性赤に強染して いるむの.

（囘）固有顆柆は殆とみられず，見られても 細胞周囲にごくわずかにあるのみで，中性赤顆粒は 黒味を帯びる程慣染しブロック状に数ケに分れた赤 褐色塊となり，核の存在む不明となるあの.

以上の如き段階がみられ時間の経過と共に滞染せ
るものが増加する，4時間後には染色さ机てない組 織球は破壊したもの以外には見られない上うになり， 濃染せるものでは運動，変形はゆるやかで，細胞周 囲よりの触手状の突起むみられぬようになり，細胞 全体が大きくふくれあがつているという感しである。 8 時間以後になると崩壊現象があらわれ，胞体は 2 〜 4 倍の大きさとなり, 胞体の境界不明瞭となり平 な感しとなり，中性赤顆粒は褪色し均質に胞体内に 谈赤の色があらわ机るようになり，細胞は内容を放 出して破壊する．ヤーヌス緑染色では添加後 $3 \sim 4$ 時間にて核周にごく少数ヤーヌス緑顆粒を認好るの みである，固有顆粒と混じて見難く，中には全く認 められないあのあある.

第4節 リチオンカルミン 培䟫36万至48時間にて, リチオンカルミンの色素 をとつた細胞が出現してくる．原組織内には相当高 浱度に染つた細胞がみられるが不明瞭である。

䋐維芽細胞は培養と共に全体が均質にリチオンカ ルミンの色に染つた感じで顆粒ははつきりしない.

組織球は核周のみ均質にリチオンカルミンの色を とり顆粒の不明のもの，胞体全体に（核を除いて） 泓漫性にリチオンカルミンの色をとり，その間に大 小不同のリチオンカルミン顆粒が存在し，大なる顆 粒は核周に多くみられるもの，又胞体内て濃いい部 分が数ヶ所（多くは1〜2 ケ所）に見られるあのが ある.

\section{第 5 節 得粒貪喰}

培養後36時間迄は增生帯に於て盛に峃球・好中球 が墨粒領喰をしたま〉遊走しているのがみら机，单 球の柋柆自喰は可成り高度であう。

峨維芽細㗙：普通には等柆貪喰は全く見られず， 伤処置骨髄の場合と同様の像をみるが，極く稀に７ 日間注射した場合に微細な整粒を胞体内に散在性に 少数認められる事がある.

組織球は貪喰度が非常に大で，弱挔大に於ても細

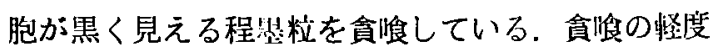
のむのでは胞休内に散在性に微紏な少煜を有するむ の，又大小不同の些粒を散在性に朖喰しているもの がある，中等度のものでは大小不同の紧笠が練胞の 中心部に集り，核が不明睹になつたもの，㤥周に密

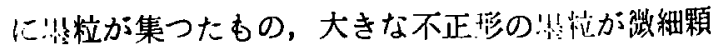
粒の間に点在するもの等がみられるが，細胞形が紀 钮形，長楕门形を呈する場合には，細胞の両端には 恣粒は少く，存在しても微細なものが多く且一核周 に集合する傾向がある，強度に貪喰せるものでは細 
胞形は多く類円形を呈し，細胞の変形や触手状偽足 ああまり見られなくなり，細胞が球状にふくれてい る如き感しですつて，細墨柆が細胞全体を嗄いそ の中に大小不同の不正形又は類円形の畦粒が存在し， 核㛎そのため胞体の 1 側に押されているむのむある。

第 6 軼国定架色所胃

織維芽細胞，組織珠の出現する時間には，增生帯 周辺部及び中間部の細胞は殆んど崩壊し破壊された ○のか散在しているが，中心部には惝生存せるもの が多く特隹球が多く見受けられる．96封間以後に なると組絊球がが䄉維芽細胞より遠くまで遊走して 中間部䎲至つているのもみられ，大型であるため染 色すると弱蛙大であ充分机判定し得ら机る.

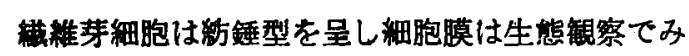
られた時よりは厚い感しで, 割合に滑らかで, 原形 罂住微細顆柆状て谈塩基性に染る。

而も徽細頼柆状のものは盷体内に於て少しくむら があり，生態筧察時の同大の光をよく反射する顆粒 㹥全く消矢している。核膜は割合に厚く稍濃染し， 核翼は非常に粗て明らかな核小体か 1 亿 3 ケ認めら れる。核は棈円形又は長楕円形で細盷の中心を占め て居る.

組織球は非常に多形性を示し，類円形，楕円形、新 簀形，不正形を示し，大小不同が甚しく，小なるは 単之同し大さのもの加非常に大型のむのまであ る. 細胞膜は大型のすの程薄く，不正型を示すむの 」うちの小数には，胞体より舌状の原形質哭起を認

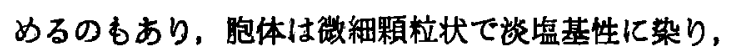
赤血球，へモジデリン，他細胞の崩壊物と思われる 麾埃粎のものを含んでいる事が多く，而むとれは大 型の細胞に多くみられる，核膜は厚く核は稍粗であ るが霍維芽細胞よりは密である。核形は楕円形、類 円形で盷体の略々中央仪存在するが貪喰の強いもの では偏在する. 又核の一部に軽い凹陥を認める事す ある. 核小体は1〜3 濃染している.

\section{第4章 総括並ひに考按}

本蝙に於ては，従来単球に類縁関係の深いと云わ れた織維芽細胞及び組織球について述へた。ささて骨

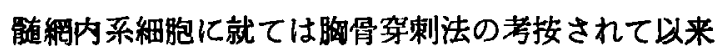
Williはギムザ架色により網内系細胞を分類し

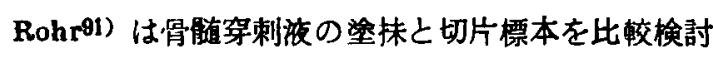
し詳細に之を分類し，本部に於ても，天野334) - 赤 绮122）の業績を始め多くの研究がなされている.

然し組維培美を用いての此の方面の研究は殆んど
見られず，䋐維芽細胞についてはその培養は最す容 易であり，他種絊胞に比し抵抗が強く且つその材料 ああらゆる䑏器から得られるため早くから行われて いる. 然し乍ら Fazzari24) は同し家鵎胎児加ら発育 した紻維芽細胞も脿器を異にすれで形に差があり形 態学的に区別しうると述べ，木村55) は細胞の形は 培養基・組織片の年令，温度の高低等の条件により 非常に专つてくると云つている. 又䄉維芽細胞の培

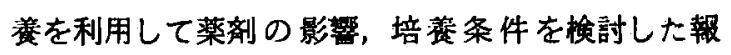

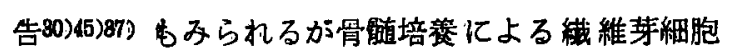
や組織球の詳細な観察を行つた者はない，よつて私 は家鬼大腿骨骨随の体外組織培甆によつて増生して くる織維芽細胞及び組織球の観察を行い，単球との 関保を蛤索した次第である。

先ず生体観察に於て縺維芽細胞は中等大の光をよ く反射する顆粒が胞体の尖端迄充満し，而も重り合 うととなく一首に並んている事は明かであるにもか \わらず，皮下組織又は心胎児隹於ける織維芽細胞 についてはその詳細な記载をみない. 然し乍ら運動 変形のない事は天野引）始め多くの学者の認めると ころである. 組織球について大小不同・多形性があ り、種々の形態をとり䵇細顆柆を有し，触手状 突起を出すとと又胞体内に異物会砟のある事仗 Sabin, 92)93) Strangway，104) 天野3)等によつて認 められているが私も全く同様の所見を得た。

生体染色乃至超生体染色では䄉維芽細胸の中性赤 顆粒の染色が軽度であり，組織球は高度に染色する 事は天野3)(皮下組織, 腹水), 岡田79) (家兔腹水),

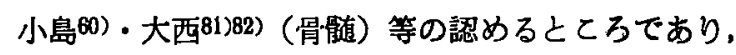
たよ゙ヤーヌス緑について天野る!は組織球は核周化密 にヤーヌス緑顆粒があらわれ，核を離れるに従つて 粗となり，乙の系粒体所見は若い組織球の場合には 稀であるとし，繀維芽細胞は極めて微少な系柆体を 見，時には全く現われないととがあると述でている が私の場合に於ては䄉維芽細胞には全く認められず， 組織球では詳細に観察していると微細固有顆絃の間 で核周にのみ非常に少数認められる事もあるし, 又 全く認め難い事あある.

カルミン摄取は緻維芽細胞には認められず，組織 球には軽度又は中等度に認めら狆るが，てれは清 野56577)，滝川(105)，大森8381)，小島60)，大西81 182）等 の所見に一致する。

留粒合喰については, 特に組織球の一大特性であ つて従来組織球の細胞鑑別に於ける主役を演して来 た. 此の貪喰能を検索するのに，教室角南102）の方 
法によると彼が「高度に畦粓貪喰を行い大小様くの 整粒を胞体に充満させている所謂 Makrophagen が 数ケ原組織の上部に現われる」と述べている如く組 織球は出現するも少数で観察に不十分である為，あ らかしめ家鬼に照汁を注射しておき骨佣内組織球に 䁷汁を貪喰させておいて被㠅培養を行い，增生帯に 緎維芽細胞，組織球の出現するのをまつて会喰状態 を観察した。尚無処置の骨噵培養を行い細胞出現後 にあらためて器汁を添加するのでは，培地が凝固し ている為笙柆が細胞迄達し得ないので貪喰能の観祭 には不適当である，さて網内系細胞としての所謂 Makrophagen の会喰能については芽賀34・森は試 験管法で最むよく頜喰する事をのへ，滝川104）は家 免・犬に墨及びリチオンカルミンを注射し超生体観 察により，又ギムザ染色でも観察し，組織球は墨粒 の細いあのや塊を領喰して領喰能の旺盛なる事を簡 単にのへている. 又贯だけを領喰しているすのと 墨・カルミンの両方を領喰しているものとを分け， 全細胞住対する百分率をみているが両者の本態につ いては言及していない，又天野3は皮下組織䌙維芽 細胞で細胞内部に壆柆の入ることは殆どなく, 病的 状態に於てのみ核の偏側乃至原形質の一部に等大の 小型乃至中等大の墨粒貪喰を示すと述へている. 私 の実験成績に於ても䄉維芽細胞には殆ど貪喰は認め られず，7 日間墨汁注射した場合に於てのみ極く例 外的に小数みられたのみである. 組織球の領喰は極 めて証盛で，大小不同の墨粒が核周に密に集合して いるを認め，而も細胞が如何なる形態をとる場合に 於てあ真喰は高度である。

固定染色所見で両者は核及び胞体はよく似た染色 態度を示し，組織球の類円型を示す場合には形热的 にす爁別し得るが，組織球が紀錘型をなす場合には 全く困難であつて，細胞形態より，又核，胞体より 丁度紻維芽細胞と組織球の中間型の状態で，あたか も両者間の移行型であるかの如き感を抱かしめる. 即ち從来両者の移行を認めている学者のあるのは， 染色標本を主として観察を行つた為であろうと考え られる.

さて単球，組織球，線維芽細胞間隹於て互に移行 しうるか否かの問題であるが先ず

I）単球と組織球との間にあつては天野3)6)の 云う老化単球と小型組織球とが問題である.

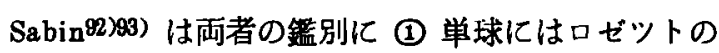
形成のある事, (2) 単球の真喰物は核然入部倿近 して現われないが，組織球会喰物は核に直接位置す
る事がある事, (3) 組織琼はヤースス緑顆粒を有し ない。

事等をあげているが，天野3）は腹腔内組織球の中 性赤, ヤーヌス緑顆顆の特性をあけ, 老化単球では中 性赤口ゼツテは恒常の特性ではなく組織球様の縁を 呈する事をのへ，岡田79）は又家兔腹腔内に家哭血液 注入後腹水細胞の中性赤超生帯染色にて単球，組織 球の鑑别をのへている. 此処沉於て天野の云う老化 単球を本実験に於て機能のおとろえた単球という意 味に解してあ組織培盖に於ては単球と組織球は次の 諸点に於て明確に区別される. (1) 偽足運動が全く異 る, 即ち峃球は細胞全周にみられる旗状偽足を布が 風にたなびく様に動かすが，組織球は触手状突起を 出沟するのみである.(2) 胞体内の固有顆柆が単球は 微細顆煜状であり，その他特有の光輝性のある変性 顆粒が見られるが，組織球は顆柆がや」大きく黒く 見え，数も多く胞体に充満し，胞体内が污れている感 じである. (3 単球の核は柔い感じで不明瞭である が明るく，組織球は顆柆が覆う様になり核の辺縁が 不明等である. (4)生体染色で単球はロゼツテを作 る事多く,組織球にはてれをみない。染色度む組織球 の方が遙かに強く中性赤顆柆の融合が著明である. (5)良喰は一般には単球が組織球より軽度であるが 程度のみによつては鑑別する事は出来ない，然し単 球の運動の遅純になつたものでは㠘柆は核凹陷部に 集り, 組織球では墨粒は胞体に遍満性に在り, 又大 小不同が甚しく細胞全体が污れている感じが強い.

(6) 固定染色所見にては老化単球が運動性を欠除し ている場合には組織球との篮別は固難な場合がある。 次江

II）織維芽細胞と組織球. 形態的に瀻維芽細胞 は紡錘形，組織球が類円形を示す場合は割合簡単で あるが，絹織球が紡鍍型を示す場合は染色所見では 上述の如く移行像であるかの如き感を抱かしめる. 関96) は運動性，形態，Mitochondriaに於て両者 は相違するとのへてている。し作ら組織培前所見に於

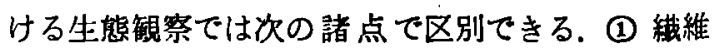
牙細胞は運動性なる特有の固有顆柆が充満し，細胞 尖端までつまつているが，組織球紀鏵型のうのでは 維維芽細胞程尖端が細く長くならず，細胞端がちぎ れたような形を示すむのああり，且つ顆柆が政細て 細胞尖端まで顆柆が入りこんでいない，但し縺維芽 稩胞のに似た顆柆の存在する事も屡々みられる。後 者に於ては運動及び触手状の糔足はないが，洔間的 に 5 〜 10分間渴们问一細胞を鹳察すると次第に変形 
を来して突起をちよ゙めて類円形組織球となり, 触手 状偽足を伸縮するようになるのを認めるが，䄉維芽 細胞にはか」る事は全くみられない。 (2) 中性赤顆 粒は組織球には非常に多く且つ融合傾向が強く大小 不同があるが，縺維芽細胞には非常に軽度で (8 食 喰は組織球は強くみられるが紻維芽細胞には例外的 にみられるのみである.

III）紻維芽細胞と単球に於ても, 培養末期に単 球が運動停止し紡鍾形を呈する事があるが，此の場 合にあ上述の生热観察，生体染色並びに貪喰能所見 により両者は明確に鑑別しえられる。

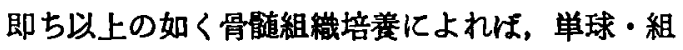
織球・織維芽細胞は夫々明確なる特徵を有し， 相互に完全に監別しうる，又緒言で述べた如く Maximow67)68), Bloom 10), Möllendorf71)72773), 関96) 等により之等の細胞種の間には相互に移行があるて とが云われて来ているのて，私はその点関しては 本研究に於て終止特に慎重に観察したつもりである が遂にどの組合せに於ても全く斯る事実を認める事 はできなかつた。即ち私の観察し得た培養期間に関 する限り, これら勫胞相互間の化生は確実に否定し 得るあので，ての点天野3）の意見に賛意を表するも のである.

かくの如く組織培養法は個々の組胞の形態学的並 飞機能的観察に優れているのみならず，細胞間の化 生についての研究，観察にも最も優秀な研究法であ るととをあらためて認み得た。

\section{全 編}

先年来教室に於ては，骨䯣体外組織培養によつて 細胞学的な基碟研究並びに臨床応用が行われて来て いるが，私はその研究の一環として特に単球を中心 として組織培養による詳細なる研究を行つた。

第 1 編に於ては健康人及び健康家兔の骨随並びに

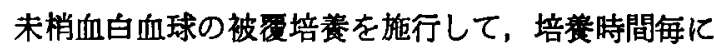
単球の遊走速度を計测し，又生態所見，中性赤生体 架色所見，基柆貪喰所見を観察した，又培養組繶を 固定染色せんとして固定液選択の予備実験を行い， Zenker-Alkohol-水錯酸液，Bouin 氏液，Carnoy 氏液か適当せるととを見出し，培莨時間毒に Totalpraeparat のま〉固定，ギムザ染色により単球の観 察を行つた. 以上の各種所見より単球の形態的機能 的特徽を明ら汃に，骨野学球と末梢血単球を比較 検討し，又単球と他細胞間の化生のないととを確認
第5章 結論

健康家兔大腿骨骨䯚体外組織培養被覆法によつて 出現する織維芽細胞・組織球について，その生態所 見, 中性赤ヤーヌス緑による生体染色，リチオンカ ルミン色素提取能，墨粒貪喰能を観察し，併せて培 羡組織の固定染色所見を観察し以てその形態学的並 びに機能的特性を検索し，更に単球との比較並びに 相互の化生の有無を吟味した。

1）緎維芽細胞は紡鏵型で特有の顆柆を有し，運 動変形は全く認められず，中性赤顆柆は少数でリチ オンカルミン色素を摄らず墨粒貪喰能は殆んどない，

2）組織球は多形性を示し，類円形のむのでは胞 体全周より触手状突起を出沒し，運動性は著明では ないが形態的変化は著しい，リチオンカルミン色素 摄取，墨粒貪喰は著明で中性赤汇濃染し，ヤーヌス 緑顆柆は少数認められる.

3）峨維芽細胞，組織球，単球の間には夫々の特 徵ある形態，運動，機能を認め，組織培養10日目迄 の観察に於ては此等細胞相互間の化生, 移行型は全 く認められない.

擱筆するに当り終始御愁篤な御指導御高閲を睗つ た恩師平木教授並びに大藤助教授に深甚なる謝意を 表します。

（本論文の要旨は昭和31年日本内科学会中国四国 地方会第11回総会に於て発表した.）

の 総 括

した.

第 2 編に於ては単球白血病患者の骨酭及び未梢血 白血球の被培培法によつて, 白血病細胞の生態観 察を行い，又培養組織の固定染色による所見も併女 て鹳察し，その特徽を明らかにした，又単球白血病 患者の末梢血白血球の液体培養法をOsgood の原法 より新たに考案し，培地としては予佮実験の結果患 者之同血液型健康人の血清を使用し、ワールブルグ 恒温槽にて振㬈培養し，白血病細狍の成熟分裂，増 殖か培地内で行わ机ている事を数的に確認した。

第 3 編に於ては煡康家鬼鹃涟の被覆培美法によつ て, 培養後24恃间以後に増生してくる䄉維芽細胞, 組織球についてその生態铜察, 中性赤ヤーヌス緑に よる生態染色，リチオンカルミン色秦摄取能，墨粒 真喰能を観察し，又培組織の固定染色により両者 
の染色像を観察し，以つて形態的機能的特性を明ら かにし，単球との比較を行い，乙れら相互間の化生 及び移行型のない事を認めた。

以上の実験及び観察より次の結論が得られた。

1）単球は独自の生態所見，細胞運動，俭足運動 及び機能的特性を有し，骨髄単球と末梢血単球との 差は殆んどなく，他細胞から又他細胞えの化生は認 められない.

2）被潭培養組織の固定染色では細胞が運動型を 示したま〉の状態で観察され，その所見は哇抹染色 標本より劣るが，尚十分な所見は得ることが出来る。

3）単球白血病患者の骨髄被膘培養法に於てはそ の増生帯所見及び白血病細胞の生態観察所見に著明 な特徽があるので, 本法は本症の確診に最す優れた
方法であり，又末梢血白血球被覆培養法によつても 略々同様の所見を得るから骨髄培羡の代用として施 行するととが出来る.

4）単球白血病患者末梢血白血球液体培養法は, 成熟形の増加する事及びその染色所見が普通の血液 塗抹染色所見と同様か，それ以上に見易いので生態 観察に不馴れな人にとつては白血病の診断上好都合 な培養方法であり，又特に成就形の少い芽球性白血 病の診断上, 被覆培養の補助手段としても価值が高 い.

5）䋖維芽細胞，組織球之単球は生態観察，生体 染色, 墨粒領喰に夫々特徽ある所見を認め, 組織培 養10日目迄の観察に於てはてれら細胞相互間の化生 及び移行像は全く認められない。

1）赤崎兼義：新渴医誌，60，1，昭21。

Inst., 14, 853, 1954.

2）赤崎兼義：日本臨床，4，340，昭21.

20) Ehrlich, P. : Berlin, 1893.

3）天野重安 : 血液学の基礎 (上巻), 丸善, 昭23.

21) Ehrlich, W. : Erg. pathol., 29, 1, 1934.

4）天野重好：日血会誌，6，269，昭17.

22) Erdmann, R. h. : Proc. Soc. Exp. Biol. Med., 15, 96, 1917.

6) 天野重安: 日血会誌, 14 (補冊)，80，昭26.

7) 天野重安：日新医学， $32 ， 651$, 昭 18 .

23) Ewald, O. : Deutsch. Arch. Klin. Med., 142, 222, 1923.

8) Aschoff, L. : Erg. inn. Med., 26, 1, 1924.

9) Aschoff. L. Verhand. deut. path. ges. Tag., 16, 107, 1913.

10) Bloom, W. . Arch. exp. Zellforsch., 5, 271, 1928.

11) Carrel, A., M. T. Burrow : J. A. M. A., 55, 1379, 1910.

12) Carrel, A., M. T. Burrow : Compt. rend. Soc. Biol., 69, 299, 1910.

13) Carrel, A., A. H. Ebeling : J. Exp. Med., 36, 399, 1922.

14) Carrel, A., A. H. Ebeling : J. Exp. Med., 44, 261, 1926.

15) Carrel, A., A. H. Ebeling : J. Exp. Med., 34, 317, 1921.

16) Commandon, J., : Compt. rend. Soc. biol., 82, 1305, 1919.

17) Cunningham, R. S., F. R. Sabin, C. A. Doan : Compt. to embryo., 16, 227, 1925.

18) Downey, H. : Handbuch of Haematology, 11, 1275, 1938.

19) Earle, W, R., E. L. Schilling : J. Nat. Cancer.

24) Fazzari, J. . Arch. exp. Zellforsch., 2, 307, 1926.

25) Fischer, A. : J. Exp. Med., 34, 447, 1921.

26) Fischer, A. . Arch. exp. Zellforsch., 3, 345, 1927.

27) Fleischmann, P. : Folia. Haemat. Archiv., 20, 17, 1916.

28) Foot, M. D. - Beitr, zur Path. Anat. zur Allg. Path. (Ziegler), 53, 446, 1912.

29) Forkner, G. E. . J. Exp. Med., 34, 625, 1921.

30）福光廉平 . 日微病誌，24，427， 1930.

31) Grossmann, W. : Beitr. zur Path. Anat. zur Allg. Path., 72, 195, 1924.

32) Haagen, E. : Arch, f. exp. Zellforsch., 3, 353, 1927.

33) Haan, J. Arch. f. exp. Zellforsch., 7, $275,1931$.

34）芳賀圭占，森英章・日血会誌，5，493，昭16.

35）原和一郎：解剖会誌，18，257, 昭16.

36）原和一郎：解剖会誌，19，250，昭17。

37）服部圭三 日微病誌，24，71，1930. 
38）平木樑：診断と治痖，43，677，昭30.

39）平木潔・日本医事新報，No. 1925，97，昭29.

40）平不潔他 3 名：最新医学，10，1582，昭30.

41）平木潔他 7 名 . 日血会誌，20，151，昭32。

42）平木潔他 6 名: 綜合臨床投稿中.

43）平木潔，大藤真：日血会誌，19，406，昭31.

44) Ingebrigsten, R. : J. exp. Med., 15, 397, 1912.

45）石井辰次：日微病誌，23，893，1929.

46）伊藤真次：ビタミン，5，452，昭27。

47) Isràelis, M. C. G. : J. Path. bact., 50, 145, 1940.

48）岩男督：日血会誌，7，195，1943.

49）岩崎一郎：岡山医誌，68，9，1315，昭31.

50) Jolly, J. : Comt. rend. Soc. Biol., 74, 504, 1913.

51）勝沼精藏：日内会誌，23，1，昭10。

52）勝田甫·組織培羕法，納谷書店，昭30。

53）川野嘉彦・未刊.

54）河嶋勇 ·日血会誌，4，71，昭15.

55）木村廉：組織培意，共立出版，昭30.

56）清野謙次：生体染色の研究及其検查術式, 南江 堂, 大 10 .

57）清野謙次 ·日病会誌，8，1，大 8 .

58）小宮悦造：日本臨床，12，542，昭29.

59）小坺孝二.日血会誌，15，229，昭27。

60）小島瑞，大西登：日血会誌，14，208，昭26.

61) Krüger, E., W. Schultz : Ergeb. Inn. Med. Kinderh., 56, 56, 1939.

62) 久米田克哉：末刊.

63）栗原操：日血会誌，8，109，昭19.

64) Lewis, M. R., W. H. Lewis : J. A. M. A. 56, 1795, 1911.

65) Lewis, M. R., W. H. Lewis . Johns. Hopk. Hosp. Bull., 22, 126, 1911.

66）牧野秀雄：ビタミン，3，43，昭25，4，450, 昭26.

67) Maximow, A. : Arch. f. exp. Zellforsch, 5, 169,1928

68) Maximow, A. : Fol. haemat., 8, 125, 1909.

69）森喜久男：十全会誌，33，962，1532，昭 3 .

70）森田博. 日血会誌，7，433，昭18.

71) Möllendorff, W. : Erg. d. Anat. u. Entw., 25, 1, 1924.

72) Möllendorff, W. : Z. Zellf. u. mikro. Anat.,
3, 501, 1926.

73) Möllendorff, M. . Z. Zellf. u. mikro. Anat., 6, 151, 1928.

74) Naegeli, O. : Blutkrankheiten und Blutdiagnostik, 5 Aufl, Berlin, 1193.

75）大藤真: 最新医学, 10, 2642, 昭 30 .

79）大藤项，亘理善治：束京医事新誌，71，454, 昭29.

77）大藤真他 2 名：東京医事新誌，71，517，昭29.

78）大藤真他 2 名 : 臨床病理, 2, 283, 昭29.

79）剛田義男：十全会誌，39，2160, 昭 9 .

80) 大谷以爾子：最新医学, 9, 110, 昭29. 10, 230, 昭30.

81）大西登：日病会誌，39，56，昭25.

82）大西登：日血会誌，14，207, 昭26.

83）大森幸夫：日病会誌，38，34，昭24。

84）大森幸夫：日血会誌，14，207，昭26.

85) Osgood, E. E. : J. A. M. A., 109, 933, 1937.

86) Osgood, E. E., T. H. Brooke : Blood, 10, 1010, 1955.

87) Osgood, E. E., I. E. Brownly, J. A. M. A. 108, 1793, 1937.

88) Pappenheim, E. V. · Fol. haem. Zent. Org., 9, 274, 1910.

89) Philipsborn, E. V. : Fol. haem., 43, 142, 1931.

90) Reschard, H., V. Schilling : Münch. Med. Woch. sch. 60, No. 2, 1981, 1913.

91) Rohr, K. Das menschlichlichen Knochenmark, Leipzig. 1943.

92) Sabin, F. R., Miller, : Downey Handbook of Haematology.

93) Sabin, F. R., : Bull. Johns. Hopk. Hosp., 32, 314, 1921.

94）坡野俊彦：日血会誌，2，777，昭13.

95) Schultze, A. . Verh. deut. path. Gesell., 23, 459, 1928.

96) 関正次：組織学, 杏林書院, 昭29.

97）千田信之：最新医学，9，1518，1646, 昭29.

98) Seemann, G. : Ziegler's, 13, 85, 303, 1930.

99）島菌㮌雄：綜合研究報告集録，医学及び楽学編， 80 , 昭28.

100）杉山繁粕：血液及び組織の新研究とその方法. 南江堂, 昭19.

101）杉山繁煇，森喜久男：十全会誌，33，616，昭 
3. 34，1370, 昭 4 。

102）角南宏: 岡山医志，68，1169, 昭31.

103）鈴木清：臨床病血会誌，3，75，昭 4 。

104) Strangway, D. H. . Arch. f. exp. Zellforsch., 8, 477, 1929.

105) Schilling, V. : Fol. Haemat., 6, 429, 1908. 106）滝川清治，平松践：血液詰議会報告集，第 5

編, 173, 炤30。

107) 田村甫.未刊。

108) Tischendorff, W. : Deut, A. f. klin. Med, 186, 272, 1940 .
109) Vannotti, A., G. Siegrist : Ztschr. ges. exp. Med., 108, 336, 1940.

110）渡辺四郎：十全会誌，35，1171，昭 5，36, 2032 , 昭 6 . 37, 687, 昭 7 .

111）元理善治：末们.

112) Wallgren, A. Arbeit. a. d. pathol. Instit. d. Univ. Helsingfors, Neue Folge, 3, 1, 1925.

113) Waldayer, W. Arch. mikr. Anat., 11, 176, 1875.

\title{
Studies on the Monocyte Series in the Bone-Marrow and Peripheral-Blood Tissue Cultures
}

\author{
Part 3. Morphalogical Comparisons of Histiocytes, Fibroblasts, and \\ Monocytes, and the Possible Mutual Transformation among \\ Themselves in the Rabbit Bone-Marrow Tissue Culture
}

\author{
By \\ Shigeru MATSUKI \\ Department of Internal Medicine Okayama University Medical School \\ (Director : Prof. Kiyoshi Hiraki)
}

By studying the vital findings, vital stainings with neutral red and Janus green, the intake of lithium carmine dye, and carbonparticle phagocytosis, in the fibroblasts and histiocytes appearing in the bone-marrow tissue culture of healthy rabbit femur by coverslip method, and also by ohserving the fixed and stained specimens of cultured tissues, the author studied the morphological and functional properties of these cells and also scrutinized the relationship of these cells with monocytes and the possiible mutual transformation.

1. Fiqroblasts are spindle-shaped, possessing peculiar granules but showing no movement or transformation at all; and they contain only a few neutral-red granules, taking no lithium carmine dye and having practically no phagocytic capacity.

2. Histiocytes are polymorphous, and those oval shaped ones have tentalce-like projections around their cell-body, which are extending and contracting. Although their motility is not so marked, their morphological changes can be observed. Histocytes on the other hand can take in lithium carmine dye and their phagocytic capacity is marked, showing a deep neutralred stain as well as a few granules stained by Janus green.

3. In fibroblasts, histiocytes and monocytes can be observed the characteristic shape, movement and function of respective cells, but there can be recognized no mutual transformation among themselves in the observations up to the tenth day of the culture. 


\section{松 木 論 文 附 図}

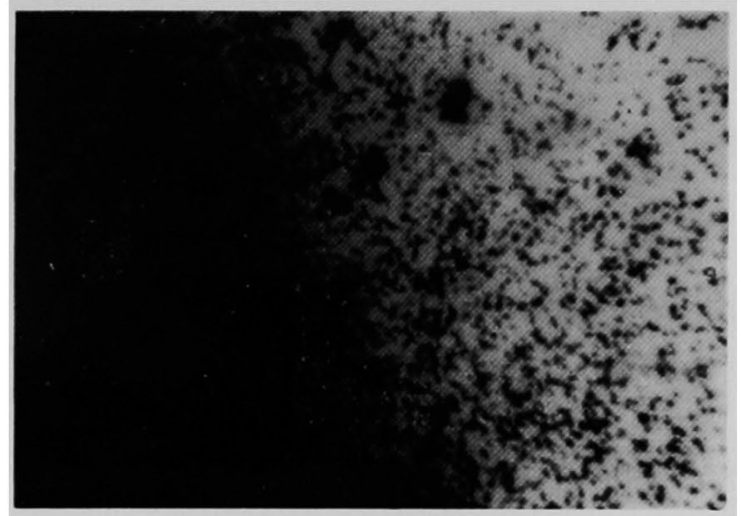

Fig. 1, 健康人末梢血白血球被覆培養增生帯

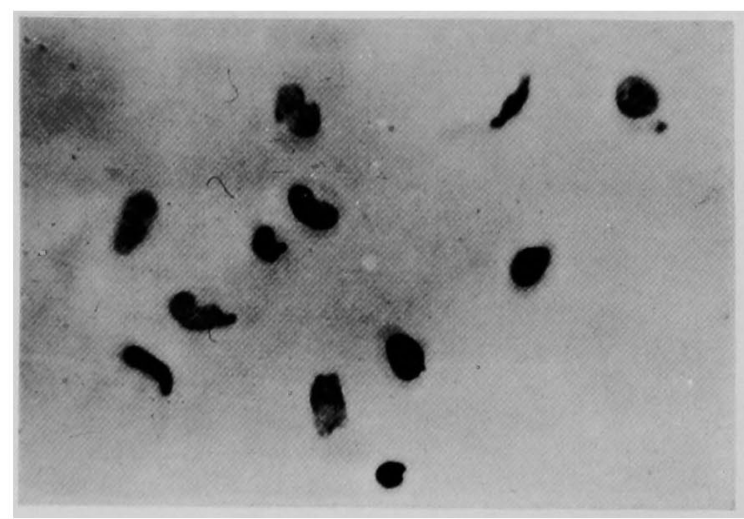

F!g. 3，単球白血病末梢血被覆培養增生帯周 辺部の単球（固定染色）

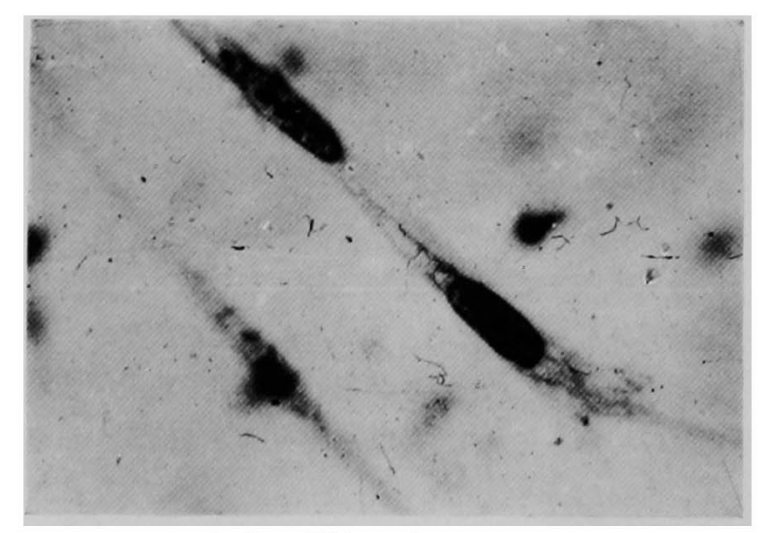

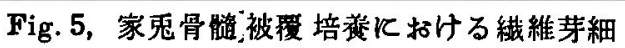
胞（固定染色）

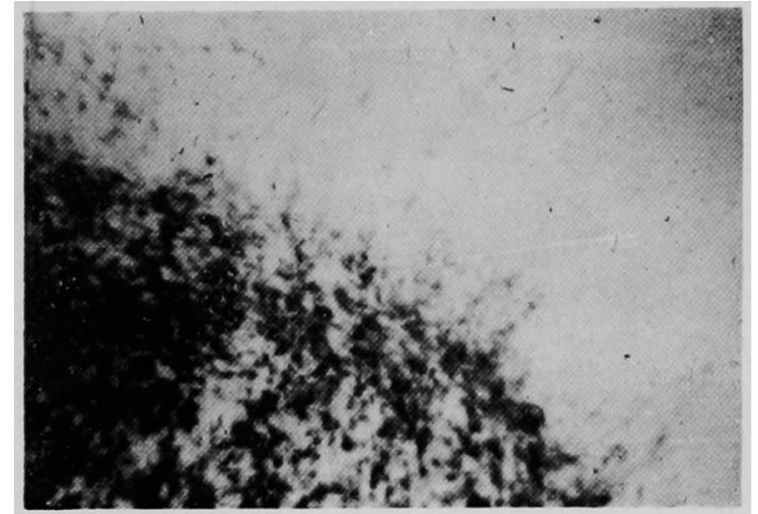

Fig. 2, 単球白血病患者末 梢血 白血球被政 培意增生帯

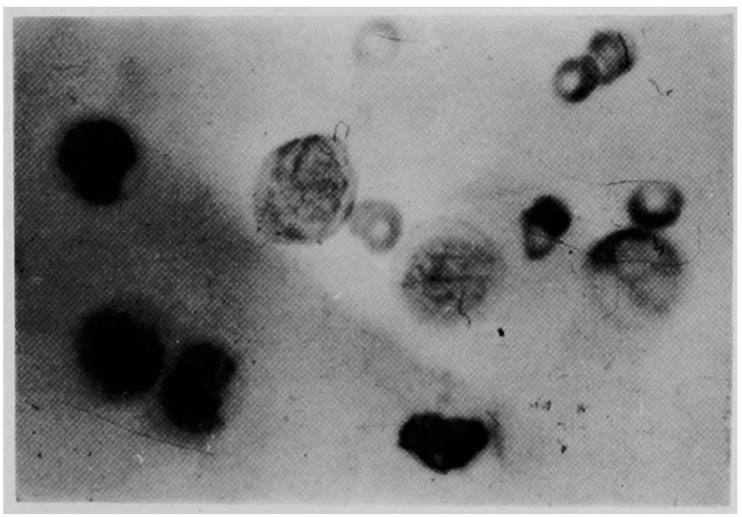

Fig. 4, 単球白血病末梢血被猺培養に括ける 単芽球 (固定染色)

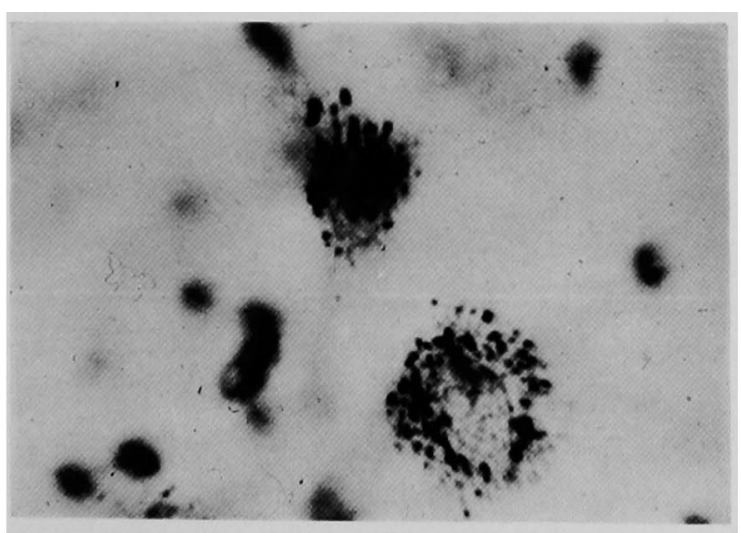

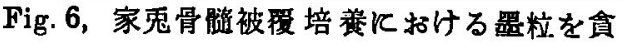
喰せる組織球 